\title{
HVAD KAN VI LAERE AF GRØNBECH?
}

\section{Nogle grundlæggende religionsvidenskabelige metodeovervejelser i anledning af J. Prytz-Johansens nye bog}

\author{
Af Per Bilde
}

\section{Indledning}

Religionsvidenskaben forekommer mig i disse år at være præget af to tendenser, dels den stadigt voksende strøm af bidrag til udforskning og belysning af enkeltproblemer $\mathrm{i}$ religionernes verden og dels den intense debat om religionsvidenskabernes metodeproblemer. Ofte er der imidlertid ingen eller kun en alt for svag forbindelse mellem disse to områder. Især er det et problem, at detailstudierne hyppigt gennemføres uden udblik til emnet, religionen og faget som helhed. Hertil svarer på paradoksal vis, at fagets metodedebat - eksempelvis som den fremtræder i det af F. Whaling udgivne værk, Contemporary Approaches to the Study of Religion (1984-85) i høj grad præges af en længsel efter helhed og integration i synspunkter, teorier og metoder (»holisme«), samtidig med at der dels er stor usikkerhed over for, om en sådan »holisme« overhovedet lader sig realisere, og dels blandt værkets forfattere markeres en generelt afvisende holdning over for de »holistiske « fors øg, der foreligger hos forskere som Eliade og Jung. ${ }^{l}$ Hertil kommer en lignende usikkerhed over for spørgsmålet om, hvorvidt religionsvidenskaben er i stand til at bidrage til løsningen af vor tids politiske og kulturelle problemer. ${ }^{2}$ Heraf udspringer endelig spørgsmålet om det personlige engagement $\mathrm{i}$ videnskaben, forholdet mellem personlig ideologi og praksis på den ene side og videnskabelig forskning på den anden side. Og heller ikke om denne sag hersker der klarhed. ${ }^{3}$ Dersom denne diagnose er korrekt, befinder religionsvidenskaben sig i en situation, der er præget af en grundlæggende usikkerhed dels med hensyn til faglig selvforståelse og metodologi og dels med hensyn til fagets rolle i samfundet.

I denne situation tror jeg, at det kan være frugtbart at inddrage Vilhelm Grønbech. Det har ofte undret mig, at denne bemærkelsesværdige 


\section{Hvad kan vi lære af Grønbech?}

danske forsker spiller så ubetydelig en rolle i den internationale debat. Men det kan naturligvis skyldes sprogbarrieren. Det er derimod vanskeligere at begribe, at han næsten heller ikke er nærværende i den danske religionsvidenskabelige og teologiske diskussion. Det $k a n$ selvfølgelig have sin årsag i, at Grønbech ikke har noget at byde på, eller at han er overhalet af tiden og passé. Men det er i så fald en sag, som bør overvejes og nærmere efterprøves. Og det er der en anledning til just nu, da J. PrytzJohansen har udsendt sin bog, Religionshistorikeren Vilhelm Grønbech (Gyldendal 1987), i hvilken der lægges vægt på, at Prytz-Johansen i modsætning til sine forgængere er religionshistorisk fagmand (side 7).

I det følgende er det da min hensigt at drøfte, om vi i religionsfaget $\mathrm{i}$ dag har noget at lære af Vilhelm Grønbech. Vi begynder med en kortfattet præsentation af Grønbech og de vigtigste af de hidtidige monografier om ham. Derpå følger en gennemgang og en kritisk drøftelse af PrytzJohansens nye bog. På dette grundlag vender vi os til Grønbech selv og forsøger at rekonstruere hans "projekt « og »metode «, hvorefter vi slutteligt kan gøre resultatet op. ${ }^{4}$

\section{Vilhelm Grønbech - et omrids af hans liv og arbejde ${ }^{5}$}

Det er i 1988115 år, siden Grønbech blev født, og 40 år, siden han døde. Han blev i 1897 kandidat i fagene dansk (hovedfag), engelsk og latin (bifag). I 1908 blev han ansat som docent i engelsk, og i 1911 overtog han Edvard Lehmanns docentur i religionshistorie, hvilket i 1914 blev omdannet til et professorat. Grønbech virkede derefter som professor ved $\mathrm{K} \emptyset$ benhavns Universitet, indtil han i 1943 gik af med pension. Sit arbejde med faget fortsatte han dog til sin død den 21. april 1948.

Vilhelm Grønbech var altså sprogmand, og i studietiden og senere studerede han mange andre sprog end sine tre fag. Hans disputats, der kom i 1902, behandler tyrkisk lydhistorie, og sprogstudierne vedblev hele livet at udgøre et kerneområde i hans arbejde. Det gælder ikke mindst det første store religions- og kulturhistoriske værk, Vor folkecet $i$ oldtiden, IIV, 1909-1912 (genoptrykt i to bind i 1955). I øvrigt er de i vor sammenhæng vigtigste af Grønbechs arbejder følgende:

»Religionsskiftet i Norden« (1913).

Primitiv religion (1915).

Religiøse strømninger $i$ det 19. århundrede (1922).

Indisk mystik (1925). 
Kampen om mennesket (1930).

Mystikere i Europa og Indien, II-III (1932).

William Blake. Kunstner, digter, mystiker (1933).

Mystikere i Europa og Indien, IV (1934).

Jesus Menneskesønnen (1935).

Hellenismen, I-II (1939-1940).

Paulus. Jesu Kristi apostel (1940).

Kristus. Den opstandne frelser. Den aldste kristne menighed

(1941).

Hellas. Kultur og religion, I-II (1942), IV (1944) og III (1945).

Kampen for en ny sjael (1946).

Frie Ord, 1-3 (1946-1948).

Angst. Religion. To foredrag, København 1951 (opr. holdt i 1947 og 1931 og først trykt i Heretica).

Hvem er min naeste? (1954).

Atombomben og andre essays (1957).

Ud over sine større religions- og kulturhistoriske værker skrev Grønbech en lang række kortere artikler og kronikker, og på Borups Højskole, Liselund, i Studenterforeningen og andre steder holdt han hyppigt folkelige foredrag. ${ }^{6}$ Endelig skal det nævnes, at Grønbech hele sit liv igennem var aktiv som musiker (organist) og digter. ${ }^{7}$

\section{Den tidligere litteratur om Grønbech}

Som en indledning til gennemgangen af Prytz-Johansens bog kaster vi et hastigt blik på hans forgængere. ${ }^{8}$ Da Grønbech døde i 1948, stod han midt i en vældig virksomhed som kulturskribent, især i Frie Ord. I brydningstiden efter 1945 fik han en betydelig indflydelse, hvilket klart kan aflæses af de mindeartikler, som hans medredaktør, Hal Koch, udgav i Frie Ord i 1948. I særlig høj grad gjaldt dette for Askov-kredsen med navne som Arnfred og Knud Hansen, Heretica-gruppen, hvor mænd som Martin A. Hansen, Thorkild Bjørnvig, Ole Wivel og Tage Hind vedkender sig deres gæld til Grønbech, og en personlighed som Arne Sørensen. ${ }^{9}$

Efter Paul W. Rubows lille hæfte $(1948)^{10}$ kom den første egentlige Grønbech-monografi i 1970, P. M. Mitchell, Vilhelm Grønbech. En indføring. Denne bog er i det væsentlige en refererende og vurderende gennemgang af Grønbechs samlede forfatterskab og den debat, som hvert enkelt skrift gav anledning til, en »indledning til Grønbechs skrifter«, som 


\section{Hvad kan vi lare af Grønbech?}

forfatteren selv formulerer det (side 9). Mitchells holdning til Grønbech er særdeles positiv. Han udtrykker en næsten grænseløs beundring for Grønbechs originalitet (side 236). Videre betegner han ham som Danmarks betydeligste "syntetiker« $\mathrm{i}$ det 20 . århundrede, idet han sammenligner Grønbechs betydning med Grundtvigs (side 237 og 248). Til debatten om Grønbechs »metode « giver bogen imidlertid intet væsentligt bidrag. Mitchell noterer naturligvis, at Grønbech søger enheden og helheden i et forfatterskab eller en kultur (side 50), og at han søger at nå dette mål ved at leve sig ind i sit emne for at anskue det indefra (side 18 og 241242). Han karakteriserer hyppigt Grønbechs fremgangsmåde som "parafraserende « (side 88,112,116,123,133, 159 og 191) og betegner ham flere gange som en »intuitiv« (side 87 og 178) og »subjektiv« (f.eks. side 143) forsker, hvis egne synspunkter ikke er til at skelne fra den sag, han fremstiller. ${ }^{11}$ I sine fors $\emptyset \mathrm{g}$ på at sammenfatte essensen i Grønbechs videnskabelige »metode « taler Mitchell om en »tolkende syntese« (side 244), eller han betegner Grønbech som en "psykologiserende religionshistoriker« (side 183). Sådanne formuleringer finder jeg imidlertid ikke tilfredsstillende, og jeg opfatter bogens afsluttende kapitel, Om at loese Grønbech, som en helt utilstrækkelig sammenfatning af, hvad der i det foregående er blevet sagt om Grønbechs fremgangsmåde.

I 1974 udkom Ejvind Riisgårds store bog i to bind, Vilhelm Grønbechs kulturopg $\phi r$. Til forskel fra den foregående forfatter medinddrager Riisgård her Grønbechs livshistorie, og bogen bygges også op på en helt anden måde end Mitchells, der ganske præcist kritiseres for ikke at nå »ind til nerverne hos Grønbech « (II, side 392). Mens Mitchell i kronologisk orden gennemgår hvert enkelt værk, bygger Riisgård sin fremstilling systematisk op om Grønbechs opgør med den europæiske kultur: Efter et forord, en indledning og et kortfattet afsnit, Angst, i hvilke dette opgør skitseres, følger fire store kapitler, et om Videnskab, der udfolder Grønbechs forståelse af historie og videnskab, et om Psykologi, der omfatter værkerne om Herder, Goethe, Schlegel, indisk og europæisk mystik, dele af Hellas og Hellenismen og store dele af bøgerne om den tidlige og senere kristendom, et om Virkelighed, der behandler Grønbechs værker om de gamle helhedskulturer, og endelig et særdeles grundigt kapitel om Grønbechs Liv og levned. Det følges af et lille afsnit om hans Tro, der behandler de poetiske værker, i hvilke Grønbechs visioner finder udtryk. Derudover rummer værket et stort materiale med bibliografiske oplysninger og fyldige registre, 


\section{Per Bilde}

en sand guldgrube for den interesserede læser. Riisgårds hovedsigte er at "påvise den indre sammenhæng i forfatterskabet« og at »fremstille og fortolke« det kulturopgør, som det er udtryk for (I, side 10). Der er tale om et meget personligt engagement, og forfatteren identificerer sig næsten uden forbehold med Grønbech, som han betegner som en »politisk-religiøs vejviser« (II, side 403), der var langt forud for sin tid med hensyn til at forudse de vældige begivenheder, som i de senere årtier er rullet ind over os: koloniernes frigørelse, Europas samling, ungdoms- og studenteroprøret, kvindebevægelsen og sidst, men ikke mindst, den $\emptyset$ kologiske krise (II, side 404 og 410). Riisgård afslutter derfor sin bog med en kraftig betoning af aktualiteten af Grønbechs kulturkritik (II, side 410).

Riisgård gør grundigt rede for Grønbechs syn på sin videnskab (I, side 57-115). Især fremhæves indflydelsen fra Herder, hos hvem Grønbech lærte, at det er historikerens mål at forstå de historiske fænomener ud fra deres egne forudsatninger, og at dette kun kan ske gennem indlevelse (I, side 73-76 og $80 \mathrm{ff}$ ). Derved er det muligt for historikeren at lytte og erfare sig frem til centrum eller helheden i den kultur eller det fæenomen, der er hans emne (I, side 83, 90 og 99 osv.). Desværre skæmmes Riisgårds ellers udmærkede redegørelse for Grønbechs »metode« af en emsig apologetik over for alle, som $\mathrm{i}$ tidens $\emptyset$ b har tilladt sig at angribe Grønbech. ${ }^{12}$ Lige så kritisabelt er det, at Riisgård opfatter Grønbechs »metode« som »uefterlignelig«, fordi den er så inderligt forbundet med hans enestående personlighed og forskertalent (II, side 345). Det er måske også grunden til, at Riisgård lige så lidt som Mitchell og - som vi skal se det - PrytzJohansen forsøger at stille Grønbech ind i en relevant forskningshistorisk sammenhæng. Ud over forbindelsen til Herder gør Riisgård ganske vist rede for Grønbechs forhold til lingvistikken og den senere strukturalisme (I, side 108-111), men han har ikke det mindste at sige om hans forhold til religionshistorien $\mathrm{i} \emptyset \mathrm{vrigt}$.

\section{J. Prytz-Johansens Grønbech-bog}

Allerede i 1948 skrev Prytz-Johansen en lille mindeartikel om Grønbech i Frie Ord, og i 1971 holdt han ifølge Riisgård (II, side 392) en forelæsningsrække om ham på Københavns Universitet.

I forhold til Mitchell og Riisgård vælger Prytz-Johansen en tredje vej. Han gennemgår ikke, som Mitchell, hvert værk for sig. Ej heller går han, som Riisgård, frem med en klar og enkel systematik. Prytz-Johansen ind- 


\section{Hvad kan vi lære af Grømbech?}

leder sin bog med en biografisk skitse, i hvilken der i beskrivelsen af Grønbechs livsløb er indflettet en præsentation af hans værker. Resten af bogen er præget af en original disposition: Først leveres der i fire afsnit 2. Foreloesninger, studenter og studier, 3. Grønbech og sjoelens erfaringer, 4. Om at loese Grønbech og 5. Videnskab - nogle generelle forudsætninger for at læse og forstå Grønbech. I de følgende fem afsnit føres vi dybere ind i de forskellige dele af forfatterskabet, der anskues under en kombineret kronologisk-systematisk synsvinkel: 6. Primitiv religion. Religionsfanomenologi, 7. Kulten, 8. Hellas, isaer kulten, 9. Andre primitive religioner, og mere fonomenologi, 10. Urkristendommen, 11. Fremstillingen og 12. Solen har mange veje.

Efter den biografiske skitse, i hvilken Prytz-Johansen etablerer sin helhedsforståelse af Grønbech, følger naturligt det lille kapitel om »forelæsninger, studenter og studier«. Vi får her et indtryk af, hvor stor en rolle den mundtlige form og kontakten med en tilhørerskare betød for Grønbech. Videre fornemmer vi, at mange af Grønbechs værker er grundlagt og formet i forelæsninger. Med kapitel 3 fører Prytz-Johansen os ind til kernen af Grønbechs arbejde, studier og religionshistoriske »metode«. Prytz-Johansen gør her Grønbechs oplevelse og erfaring, også med mystikken, til grundlaget for hans arbejde. Det forstår jeg således, at Grønbech besad en enestående indlevelsesevne, og at det ifølge Prytz-Johansen var den, der satte ham i stand til at yde sin usædvanlige indsats, altså en position, der svarer til Riisgårds. Ind i dette afsnit flettes dels en drøftelse af spørgsmålet om Grønbech som mystiker og dels en fremstilling af Grønbechs værker om mystikere. I kapitel 4 hjaelper Prytz-Johansen os videre ved at forklare Grønbechs begreb om virkelighed og ved at indføre os i hans anvendelse af humor og ironi.

Derefter er Prytz-Johansen i stand til at gøre rede for Grønbechs forståelse af videnskab. På den ene side betegner Grønbech uden videre sig selv som en »objektiv historiker der gengiver sandheden rent og purt «. ${ }^{13}$ Mennesker, kulturer og religioner skal ifølge Grønbech skildres ud fra deres egne forudsaetninger. Men for at nå dette mål er det på den anden side nødvendigt, at forskeren sætter sin egen person på spil. Det fordres, at han "glemmer« sine egne og sin tids yndlingstanker, at han så at sige "mister sig selv« for i stedet at leve sig ind i sit emne (side 83-85). Det afgørende er imidlertid, hvordan dette konkret kan foregå, og her er det, sammenhaengen, centrum eller helheden kommer ind i billedet. ${ }^{14}$ For at 
forskeren kan få fat på sit emne fordres der en helhedsopfattelse (side 90), og denne vindes atter ved studier af sproget, især dettes grundlæggende udtryk (side 86-90). Derfor er den filologiske metode og det intense arbejde med et menneskes eller en kulturs sprog af afgørende betydning for at vinde et »objektivt« billede af emnet.

I kapitel 6 viser Prytz-Johansen, hvordan Grønbech ad denne vej nåede til en i samtiden ny forståelse af primitiv religion. I sin afhandling herom fra 1915 brød Grønbech med det gængse evolutionistiske billede af naturfolkene og tolkede i stedet disses religion som udtryk for en virkelighed og en kultur, der er helt anderledes end vor. Det samme grundsyn prægede hans værker om nordboerne og om religionsskiftet i Norden. Ved en sådan kongenial læsning af kilderne lykkedes det ifølge Prytz-Johansen Grønbech at leve sig ind til en helhedspræget kulturoplevelse, som dannede grundlaget for hans fremstilling af sagen (side 117). Denne grønbech'ske »metode« betegner Prytz-Johansen derefter som »religionsfænomenologisk « (side 124) eller rettere som »fænomenologi på psykologisk basis« (side 125-126, jf. 144-145).

De følgende kapitler er alle kortfattede og bringer kun lidt nyt. I kapitel 7 forklares det, at Grønbech i 1916-1918 fik et klarere blik for kultens betydning i primitiv religion. Kapitel 8 om Hellas er yderst kortfattet og berører i realiteten kun bind I af dette værk, som kan sidestilles med Vor folkeat $i$ oldtiden. Endelig afslutter kapitel 9 behandlingen af denne del af forfatterskabet. I kapitel 10 gøres der kortfattet rede for Grønbechs tre bøger om Jesus, Paulus og urmenigheden og for den modtagelse, som de fik i samtiden. Bogen afsluttes med en beskrivelse af Grønbechs fremstillingsform. Det betones, hvilket slid det var for Grønbech at skrive, og vi hører bl.a., at han ofte skrev et afsnit om en 7-8 gange (side 161), ja, et enkelt ikke mindre end 15 gange (side 162).

Prytz-Johansens bog har sin styrke i forfatterens imponerende overblik over det samlede materiale (incl. breve og private forelæsningsnotater) og i hans mangeårige personlige kendskab til Grønbech, hvis elev han er. Alligevel "mætter « og tilfredsstiller denne bog mig ikke. Det må naturligvis fastholdes og respekteres, at den er og vil være en bog om religionshistorikeren Vilhelm Grønbech, og at Prytz-Johansen til forskel fra Mitchell og Riisgård "på faglig baggrund < vil> bringe en redegørelse for Grønbechs erfaringer, tanker og metoder « (side 7). Dermed mener forfatteren måske, at han har sikret sig imod kritik for den svage placering, 


\section{Hvad kan vi lare af Grønbech?}

han har givet den betydningsfulde side af Grønbech, der omfatter hans kulturkritik. Sagen berøres ganske vist flere gange i fremstillingen, ${ }^{15}$ men den har langt fra fået den plads, som den faktisk indtager i Grønbechs forfatterskab. Det er nemlig ikke kun i de kulturkritiske skrifter, Grønbech er kritisk over for den europæiske civilisation. Det er han også i de »videnskabelige « værker. Som eksempler kan nævnes, at Grønbech flere steder i Hellenismen foretager kritiske sammenligninger mellem hellenismens og vor kultur eller mellem hellenismen og andre kulturer. ${ }^{16}$ Det samme kan vi møde i Vor folkecet (f.eks. I, side 171-173), i »Religionsskiftet i Norden« (f.eks. side 92-93) samt i Kristus (side 116-118). Omvendt inddrager Grønbech næsten altid historisk og kulturhistorisk materiale i de kulturkritiske skrifter, mest udtalt vel i Kampen for en ny sjol og i Hvem er min noeste? Det må derfor - med Riisgård og mod Prytz-Johansen - fastholdes, at Grønbechs kulturopgør udgør en uadskillelig del af hans religions- og kulturhistoriske arbejde.

Videre finder jeg det kritisabelt, at Prytz-Johansen gør så lidt ud af de betydningsfulde værker om Hellas (vel at mærke bind II-IV) og Hellenismen samt af andre vigtige arbejder som William Blake og Religiфse strømninger i det 19. århundrede. Prytz-Johansen lægger klart vægten på primitiv religion, hvilket imidlertid kun ville kunne retfærdiggøres, dersom hans bog havde fået en titel i stil med Vilhelm Grønbech og primitiv religion. Men den generelt formulerede titel, som forfatteren faktisk har givet sin bog, fremkalder med nødvendighed den her fremsatte kritik. Jeg må derfor konstatere, at Prytz-Johansen ikke blot i alt væsentligt udelader Grønbechs kulturkritik, men at han i realiteten kun har medtaget én del af det religionshistoriske forfatterskab, mens andre er udeladt.

Flere andre sider af bogen kan kritiseres. Jeg savner således både registre og en fuldstændig bibliografi. Jeg føler mig heller ikke sikker på, om den valgte disposition er heldig, ligesom de indførende kapitler 3-5 ikke forekommer mig helt vellykkede. Min vægtigste indvending er dog den, at det efter mit skøn ikke er lykkedes Prytz-Johansen at give en klar og overbevisende fremstilling af Grønbechs religionshistoriske »metode«. Forfatteren har naturligvis ret i - mildt, alt for mildt - at kritisere Grønbechs besynderlige aversion mod begrebet metode. ${ }^{17}$ Han har også haft held til at beskrive vigtige aspekter eller faser af denne som oplevelse/erfaring, indlevelse og helhedsforstålse via en nøje undersøgelse af sproget. Men det bliver $\mathrm{i}$ bogen aldrig rigtig klart, hvad religion egentlig er for 


\section{Per Bilde}

Grønbech, og Prytz-Johansens forsøg på at sammenfatte Grønbechs særlige »metode« som »religionsfænomenologi« eller »fænomenologi på psykologisk basis « finder jeg forvirrende snarere end klarende. Forklaringen herpå er måske, at Prytz-Johansen i virkeligheden deler Grønbechs uvilje mod metodologi. Derpå kunne følgende formulering tyde: »Vilhelm Thomsen lod sig ikke lokke af hypoteser men lod sine tanker bygge på solide resultater. Det ideal overtog Grønbech «. ${ }^{18}$ Hertil kommer, at PrytzJohansen lige så lidt som sine to forgængere forsøger at placere Grønbech i en forskningshistorisk kontekst, hvilket egentlig er forbløffende, når man tænker på, at de alle tre skriver om en forsker, som i sit arbejde lagde en altafgørende vægt på at forstå og skildre fænomenerne i deres sammenhæng. ${ }^{19}$ Endelig må jeg beklage, at Prytz-Johansen intetsteds i sin bog drøfter spørgsmålet, om vi i dag kan lære noget af Grønbech.

\section{Gronbechs »projekt «}

Ser vi tilbage på de tre gennemgåede monografier, kan det konkluderes, at vi er vel hjulpne med hensyn til belysningen af Grønbechs liv og hvert enkelt af hans værker. Jeg finder endvidere, at Riisgård har ydet en bemærkelsesværdig indsats for at fremstille og aktualisere Grønbechs kulturkritik. Anderledes forholder det sig med Grønbechs »metode«. Man kan ganske vist ikke påstå, at de tre forfattere ikke har behandlet dette centrale tema. Det har de alle tre, og da især Riisgård og Prytz-Johansen. Men behandlingen forekommer mig ikke helt tilfredsstillende. Dels efterlader den Grønbech som en kontekstløs ener i forskningshistorien, og dels savner jeg en adækvat sammenhængende og nuanceret beskrivelse eller måske rettere tolkning af hans »metode«. I det følgende skal jeg i kortfattet form selv forsøge at løse disse to opgaver. Først forsøger jeg dog rekapitulerende at rekonstruere, hvad vi kan kalde Grønbechs »projekt« - hans videnskabelige og kulturkritiske livsværk - $o g$ at placere dette i en større idéhistorisk sammenhæng. Derpå følger en sammenfattende tolkning af Grønbechs historiske eller religionshistoriske »metode«, som jeg vel at mærke bestræber mig på at relatere til de forskningshistoriske sammenhænge, som Grønbech hører hjemme i. Endelig skal vi i konklusionen gøre resultatet op og overveje Grønbechs aktualitet og relevans i dag.

Som antydet $i$ det foregående afsnit, er jeg overbevist om, at Riisgård har ret $i$, at Grønbechs kulturkritik udgør en uadskillelig del af hans videnskabelige - historiske, kultur- og religionshistoriske - arbejde. Men 


\section{Hvad kan vi lære af Grønbech?}

underbetoningen af denne tese i Prytz-Johansens nye bog kræver, at vi her kort vender tilbage til sagen. For yderligere at »bevise « denne sammenhæng kunne der anføres endnu flere »skriftsteder « hos Grønbech end dem, der allerede er lagt på bordet, ${ }^{20}$ ligesom jeg kunne henvise til kyndige elever og analytikere af Grønbech. ${ }^{21}$ Men en sådan fremgangsmåde ville næsten være udtryk for en misforståelse af Grønbech, fordi det er så oplagt, at vi her står ved selve kernen i hans arbejde.

Grønbech opdagede allerede i sin ungdom, at den gamle nordiske kultur var præget af en fascinerende livskraft. Her herskede sloegtskabet og forbundet dermed fallesskab, sammenhoeng og harmoni. Derfor var denne kultur præget af en helt anden virkelighed og virkelighedsopfattelse end vor. Det varede ikke længe, før Grønbech indså, at noget lignende gælder naturfolkenes kulturer og samfundene i det gamle Indien, Israel og Hellas, lige som det i vid udstrækning gælder for den folkelige kristendom i Europa langt op i tiden. ${ }^{22}$ Samtidig kunne Grønbech naturligvis ikke undgå at bemærke, at den europæiske kultur i sine ledende lag og fremherskende træk mangler disse selvsamme kendetegn. Den europæiske kultur er ifølge Grønbech i stedet præget af splid - splid i mennesket og mellem mennesket og dets omgivelser, splid mellem legeme og sjæl, mellem tanke og handling, mellem mennesket og naturen, mellem mennesket og dets arbejde og mellem individ og fællesskab. ${ }^{23}$ Denne tilstand af splid i menneske og samfund giver sig udtryk overalt i kulturen. Grønbech finder den således i den angst, der præger det moderne Europas ånds- og sjæleliv. ${ }^{24}$ Han finder den endvidere i det træk, at videnskab og kunst $\mathrm{i}$ Europa er adskilt fra folkets daglige liv for i stedet at leve i hver deres eget isolerede univers. ${ }^{25}$ I forlængelse af dette forhold peger Grønbech på, at den enkeltes ansvar over for fællesskabet i Europa er blevet indskrænket eller næsten helt er forsvundet. ${ }^{26}$ Det samme gælder det grundtræk, at religionen i det moderne Europa har ændret sig fundamentalt og ikke længere spiller den kulturbærende rolle, som den spiller i de primitive kulturer, og som den også tidligere har spillet i det kristne Europas folkelige kultur. ${ }^{27}$ Grønbech stod således for et vældigt opgør med det Europa europæiske traditioner, religion og videnskab - der havde ført frem til verdenskrigene, ødelæggelsen af naturen, nedværdigelsen af mennesker og en kultur uden ansvar og fællesskab.

Mens den første opdagelse afspejler sig i Vor folkeat, Primitiv religion og »Religionsskiftet i Norden«, finder vi den anden i Religiøse strømninger 
i det 19. århundrede og - endnu mere udtalt - i de kulturkritiske værker. Det er dog vigtigt at fastholde bevidstheden om, at det ikke kun er i de sidste, at Grønbech fremlægger kulturkritiske og kultursammenlignende betragtninger, men at dette også sker i de videnskabelige værker, således som det er dokumenteret ovenfor. Det forekommer mig derfor velbegrundet at hævde, at Grønbech fra et tidligt tidspunkt så det som sin livsopgave at skildre disse to kulturformer og at drage aktuelle ideologiske for ikke at sige politiske konsekvenser deraf. ${ }^{28}$ Under dette arbejde gik det hurtigt op for Grønbech, at spliden i Europas kultur har sine rødder i kristendommen og - gennem og bag ved denne - i hellenismen. Denne indsigt må antages at være årsagen til, at Grønbech i en lang periode $\mathbf{i}$ 1930'erne og 40'erne fordybede sig i netop disse to emner. Og det vel at mærke samtidig med, at han stærkere og stærkere gjorde sig gældende som kulturkritiker. ${ }^{29}$

Grønbechs kulturopgør er således indarbejdet $\mathrm{i}$ hans videnskabelige arbejde næsten fra første færd. Det var derfor kun logisk, at han tidligt og fra ca. 1930 med stigende styrke drog den konsekvens, at han som videnskabsmand også havde et ansvar over for sin egen tid og sit eget samfund. Nemlig et medansvar for at påvise og bekæmpe de nedbrydende kræfter i Europas kultur og for positivt at medvirke til at opbygge en ny kultur. Denne kultur kunne han ikke på forhånd beskrive i enkeltheder, men det var i alt fald et samfund, i hvilket spliden var overvundet, og som var præget af den enkeltes ansvar for livet, samfundet og næsten. ${ }^{30}$ Grønbech fordrer derfor en »omvendelse «, ${ }^{31}$ og han kæmper for en ny tro, en ny sjæl, et nyt menneske, en ny virkelighed og et nyt samfund, præget af en ny myte, en ny religion, en ny helhed og en ny harmoni, dvs. en ny kultur, hvor livets kræfter hersker, således som de gjorde det og gør det i de gamle helhedskulturer, og således, som Grønbech mener, at det er tilfældet hos Jesus og William Blake. Det er alt dette, Grønbech beskæftiger sig med i de utopiske afsnit af de kulturkritiske kampskrifter, almentilgængelige artikler og folkelige foredrag.

Grønbechs opgør med den europæiske kultur er således radikalt. Han skildrer uden nåde menneskets nedværdigelse både i selve det moderne Europa og i dets aflæggere og kolonier. Europæernes udryddelse af andre folkeslag og deres ydmygende behandling af andre kulturer hænger for Grønbech logisk sammen med de elendige kår, som arbejderklassen blev budt under kapitalismen forud for Verdenskrisen i 1929. Imperialisme og 


\section{Hvad kan vi lære af Grønbech?}

kolonialisme, negerslaveri og proletarisering er alle konsekvente følger af den europæiske kultur, i hvilken foragten for andre folkeslag var kædet sammen med foragten for folkelig kultur. Denne foragt hænger igen sammen med evolutionstanken, som i forlængelse af kristendommens eksklusivitetskrav og hellenismens adskillelse af sjæl og legeme betragter den europæiske civilisation som kulturens højdepunkt og historiens mål, hvorfor denne også er i sin gode ret til at byde og herske. ${ }^{32}$ Hermed korresponderer atter vor kulturs samvittighedsløse udbytning af naturen og det barbari, der udfoldedes i de to verdenskrige, og som nåede sit højdepunkt med atombomben. Alle disse Europas særlige præstationer hænger for Grønbech sammen, og han tolker dem alle som udtryk for spliden i Europas kultur, for individualismen, for den europæiske idealisme og for den dermed sammenhængende foragt og angst for jorden, kroppen og kødet, dvs. de kristne og hellenistiske traditioner i europæisk kultur. ${ }^{33}$

Dermed kan vi placere Grønbech på linie med det moderne Europas visionære utopikere. Han er klart i slægt med Marx og de utopiske socialister både i sin kultur- og samfundskritik og i sin utopi. Hvad Marx kaldte fremmedgørelse, kaldte Grønbech splid. Han kunne også meget konkret kritisere kapitalismen ${ }^{34}$ og ligeså konkret sætte sin lid til arbejderbevægelsen. ${ }^{35}$ Men alligevel sætter Grønbech ind et helt andet sted end Marx, nemlig ved kulturen og det enkelte menneske. Derved er Grønbech også i slægt med Grundtvig, som han selv beundrede i modsætning til Kierkegaard. ${ }^{36} \mathrm{Vi}$ finder hos Grundtvig den samme romantiske sans for historien og det oprindelige folkelige fællesskab. ${ }^{37} \mathrm{Og}$ som i Grundtvigs tilfælde er der hos Grønbech tale om den idé, at en fornyelse af samfundet forudsætter en fornyelse af åndslivet, dvs. af religionen og kulturen. Eller rettere sagt, at begyndelsen til en fornyelse af samfund og kultur går gennem det enkelte menneskes fornyelse af sig selv. Riisgård har endelig ret $i$, at Grønbech på sin vis foregreb 1960'ernes og 70'ernes positivismekritik, ungdomsoprør og økologiske bevægelse. ${ }^{38}$

Anskuet på denne måde virker Grønbech som samfundskritiker og utopiker nok så vedkommende i dag som socialismen og marxismen. Eller rettere sagt, han virker som en nødvendig korrektion til socialismen. ${ }^{39}$ Det kan hævdes at være en svaghed ved Grønbech, at han har så lidt at sige om økonomien og spørgsmålet om magten i samfundet. På den anden side er Grønbech netop derved, at han sætter religion og kultur i centrum, måske mere i pagt med vor situation $\mathrm{i}$ dag. Vi har nemlig oplevet en 
række hændelser, der rettelig kan tolkes som symptomer på socialismens og marxismens fallit. ${ }^{40}$ Kravet i vor kultursituation må derfor nok især være et krav om en menneskelig og kulturel fornyelse. Grønbech må derfor betegnes som en original kulturreformator, som i det væsentlige må siges at være vedkommende også i vor tid.

\section{Grønbechs »metode«}

Af denne beskrivelse af Grønbechs "projekt« udspringer imidlertid et væsentligt spørgsmål til hans videnskabelige metode. Af »projektet« følger nemlig, at Grønbech optræder som missionær, agitator og propagandist, hvorfor hans læsere naturligvis må nære den allerstørste betænkelighed ved den måde, hvorpå han behandler sit stof. Er der her ikke tale om en subjektivitet og en vilkårlighed, som man ikke kan tage alvorligt i videnskabens verden? Det er der i alt fald mange, der har ment. Jeg har allerede nævnt, at Mitchell flere gange kritiserer Grønbech for »subjektivitet $\ll .{ }^{41}$ Hertil svarer anklager mod Grønbech for at sammenvæve sit emne og sine egne tanker, så man ikke kan skelne det ene fra det andet. ${ }^{42} \mathrm{Vi}$ dere er Grønbech blevet kritiseret for at være »romantiker ${ }^{43}$ og for at lade sin »intuition « dirigere arbejdet, hvor sunde videnskabelige metoder ellers havde været på deres plads. ${ }^{44}$ Kritik af denne art er blevet fremført mod både Vor folkeaet, Hellenismen og Hellas. ${ }^{45}$ Men den har især lydt stærkt mod Grønbechs tre bøger om urkristendommen, som ved deres fremkomst blev kritiseret voldsomt af samtidige teologer. ${ }^{46}$

Denne kritik for subjektiv vilkårlighed lyder indlysende rigtig. Men den virker samtidig letk $\emptyset \mathrm{bt}$ og forhastet. Den forenkler i virkeligheden en problematik, som hos Grønbech er langt mere kompleks. I næsten alle hans videnskabelige værker er der faktisk tale om den mærkelige subjektive objektivitet eller objektive subjektivitet, som Prytz-Johansen har ganske godt fat $\mathrm{i}^{47}$ Grønbech er naturligvis på det rene med, at subjektiviteten er uomgængelig, når det gælder historisk forskning. Det er et levende menneske, der arbejder med et materiale, der er skabt af andre levende mennesker, og forskeren kan kun nå disse andre mennesker gennem sit eget jeg. Med dét gælder det for forskeren om at forstå en anden og fremmed verden, hvad enten der er tale om en anden kultur, en anden religion eller et andet menneske. ${ }^{48}$ Og det sker ifølge Grønbech ved at opleve eller erfare det fremmedartede. ${ }^{49}$ Oplevelsen skaber forståelse, og ved hjælp af forståelsen sættes forskeren i stand til at leve sig ind i sit emne. ${ }^{50}$ Først 


\section{Hvad kan vi lære af Grønbech?}

derefter kan forskeren skildre det, og karakteristisk nok betegner Grønbech denne sidste del af processen som gendigtning, gengivelse eller genskabelse. ${ }^{51}$ At drive humanistisk forskning er derfor ifølge Grønbech en højst personlig og dermed subjektiv sag. ${ }^{52}$

Som vi så det hos Prytz-Johansen, indebærer denne bestemmelse af den videnskabelige forsknings subjektivitet imidlertid ingen indrømmelser til vilkårlighed. Og Grønbech insisterer samtidig på, at han netop gennem denne uomgængelige subjektive tilgang sikrer og værner objektiviteten. ${ }^{53}$ Et andet sted formulerer Grønbech denne dialektiske opfattelse på denne måde:

I denne åbne bekendelse af at al videnskab er personlig, er gendigtning, om man vil, ligger ikke den allersvageste indrømmelse til vilkårlighed. Vi har ikke opgivet et gran af kravene om absolut, objektiv sandhed. ${ }^{54}$

Der er altså på én gang tale om en meget personlig indsats og om at sætte det personlige jeg med dets fordomme og præferencer til side. På den ene side gælder det om at mobilisere alle det forskende subjekts kræfter i en aktiv indsats, og på den anden side taler Grønbech om at suspendere forskerens eget jeg med alle dets medbragte forudsætninger. ${ }^{55}$ Forskeren må så at sige miste sig selv for at finde sit »objekt«. Han må meget bevidst sætte sig selv til side for derefter med al sin fantasi og alle til rådighed stående midler (»metoder« kan vi sige) at forsøge at lytte og leve sig ind $\mathrm{i}$ sit emne, så han bliver i stand til at skildre dette indefra ${ }^{56}$ og på dets egne vilkår. Det er derfor, Grønbech taler så meget om at genfortaelle, genfremstille, gendigte eller genskabe den tid, den kultur eller det menneske, han arbejder med. ${ }^{57}$ Med disse og beslægtede formuleringer søger Grønbech efter min opfattelse at sikre, at den uomgængelige subjektivitet i forskningsprocessen ikke skader den uopgivelige objektivitet. ${ }^{58}$

$\mathrm{Nu}$ kunne man misforstå Grønbechs tale om forskerens fantasi og indlevelsesevne derhen, at kun den originale ener, at kun forskeren, der tillige er kunstner, skulle være i stand til at gennemføre dette program. ${ }^{59}$ Det er på ingen måde tilfældet. Grønbech foreskriver nemlig en ganske bestemt fremgangsmåde eller »metode« for det forskende subjekts nærmere omgang med sit materiale, nemlig den dialektiske bevægelse mellem helhed og sprog, således som vi så det under gennemgangen af PrytzJohansens bog. Hvad enten der er tale om en person, en religion eller en kultur, så er det helheden og sammenhængen eller midtpunktet og centrum,,$^{60}$ der er afgørende, og som det gælder om at få fat på. I forordet til 
bind I af Mystikere i Europa og Indien udtrykker Grønbech dette grundsyn:

En videnskabelig forståelse af åndelige fænomener må nødvendigvis hvile på en helhedsopfattelse. Det enkelte ord har ingen mening i sig selv, som kan uddrages ved grammatik og lexikon; ordenes betydning er givet i den plads de fylder inden for et samstemt hele, det vi plejer at kalde kultur. Løsrevne citater kan derfor aldrig udtømme en levende tanke, der henter sin skjulte kraft gennem skjulte forbindelser med alle de andre tanker som lever i samme hjerne. Det er forskerens pligt at leve sig ind i den kultur eller det menneske, han vil skildre, til de fremmede tanker springer frem af hans egen helhedsforståelse.

Trods Grønbechs kritiske bemærkninger om »det enkelte ord « er der faktisk ingen anden vej frem end sproget og da især dettes centrale ord og vendinger, "sprogets musik «, som Grønbech kan tale om. ${ }^{61}$ Det er sådan, Grønbech i praksis går frem både i Vor folkecet, Hellas og andre af de store videnskabelige værker. Det er derfor, sprogstudierne er så afgørende i Grønbechs liv og arbejde. Det er altså filologien helt ned til morfologi, syntaks, tekstkritik og konkordansarbejde, som udgør hovedhjørnestenen i Grønbechs »metode « trods hans egne forbehold over for begge disse begreber. ${ }^{62} \mathrm{Vi}$ kan således konkludere, at Grønbechs »metode« således anskuet præges af en høj grad af objektivitet. ${ }^{63}$

Én sag er imidlertid Grønbechs »metode«. En anden er den måde, han praktiserer den på. Mens Grønbech høstede megen anerkendelse for Vor folkecet og Hellas, har nogle kritiseret ham for i Hellenismen og i bøgerne om urkristendommen ikke at have efterlevet sit eget program om en saglig fremstilling, i hvilken han holder sin egen dom tilbage. ${ }^{64}$ Naturligvis kan der findes eksempler på, at Grønbech har forsyndet sig på denne måde. ${ }^{65}$ Men i det store og hele finder jeg dog, at han også i Hellenismen, Paulus og Kristus har efterlevet sine tanker om subjektiv objektivitet, om end hans egen holdning til sagen her og der kommer klart frem (jf. ovenfor). Så vidt jeg kan bedømme, er det kun i Jesus, at Grønbech for alvor er kommet til kort. Jesus bliver nemlig ikke placeret og tolket i den jødiske sammenhæng, han hører hjemme i. Grønbech plumper i med begge ben og gentager sine utallige forgængeres fadæser med at beskrive Jesus som en uhistorisk skikkelse, en ener, der svaver i den tynde luft oven over historien og ene af alle er ubestemt af sin kontekst. ${ }^{66}$ Her fremstiller Grønbech virkelig ikke Jesus, men sin Jesus. ${ }^{67}$

Men når det videnskabelige arbejde er gjort, - af og til sker det, som vi har set det, allerede i det videnskabelige værk - vender Grønbech til- 


\section{Hvad kan vi lare af Grønbech?}

bage til sin egen tid og sin egen kultur. Dog ikke upåvirket af sine studier, netop fordi forskeren er et levende menneske, som i sit stof og sit emne har mødt udtryk, der er skabt af andre levende mennesker. Han er under sin forskning blevet konfronteret med andre kulturer og andre værdier. $O g$ efter at have levet sig ind i dem og genfremstillet dem, slipper han ikke for at tage personligt stilling til dem. Grønbech er derfor aldrig den samme, når han vender tilbage, som dengang han »drog ud«. For ham er det derfor uomgængeligt, at der følger en kulturreflekterende fase efter den videnskabelige. Her tager han så stilling både til den kultur, han har studeret, og til sin egen, som han konfronterer med dens rødder, forudsætninger og modsætninger. Men der er vel at mærke tale om to klart adskilte processer, selv om de begge er lige nødvendige for Grønbech.

Med denne fremstilling har vi ikke blot forsøgt at tegne et omrids af Grønbechs »metode«, men også indirekte placeret ham i den forskningshistoriske sammenhæng, han rettelig hører hjemme i. Som sam- og eftertidens religionshistorikere var også Grønbech filologisk og historisk orienteret, selv om der ikke dermed er sagt så meget. Hans »holistiske« sans for helheden er nok så original og forbinder ham med samtidige og især senere strømninger inden for etnografi, antropologi og sociologi, som Grønbech i $\emptyset v r i g t$ ikke havde meget til overs for. ${ }^{68}$ Tanken om en kultur som en levende organisme er nok romantisk og formodentlig overtaget fra Herder. ${ }^{69}$ Men samtidig er der noget nyt og originalt i den idé, at religion og kultur er kædet sammen som legeme og sjæl i en integreret helhed. ${ }^{70}$ Det er en tanke, der først for alvor er brudt igennem i religionsvidenskaben efter 2. Verdenskrig, og det er en tanke, der er så aktuel, at den indtager en central placering $\mathrm{i}$ det $\mathrm{i}$ indledningen næunte værk, Contemporary Approaches to the Study of Religion. ${ }^{71}$

Med sin radikale kritik af evolutionismen og etnocentriciteten i europæisk kultur og videnskab er Grønbech fremme i forreste række af sin tids religionsvidenskab. Den forbinder ham især med den lidt yngre van der Leeuw og den lidt senere såkaldte religionsfoenomenologiske skole. Det samme gælder flere led i Grønbechs »metode«, især hans tanke om, at forskeren for at få fat på sit emne må suspendere sine egne medbragte ideer og forestillinger. Den svarer til »religionsfænomenologernes« begreb om epoché. ${ }^{72}$ Grønbech er ligeledes beslægtet med denne skole ved sine ideer om forståelse, indlevelse og om at fatte og fremstille sit emne indefra. I disse henseender er Grønbech således i god overensstemmelse med 
samtidige strømninger i religionshistorien. Der er imidlertid også forskelle mellem ham og den »religionsfænomenologiske« skole, idet Grønbech ikke opfatter religion som en kategori sui generis og ikke lider af denne skoles angst for reduktionisme og distance. ${ }^{73}$ Grønbechs suspensionstanke erindrer imidlertid også om Bultmanns næsten samtidige overvejelser over, om »forudsætningsløs eksegese er mulig «. ${ }^{74}$ Overhovedet finder jeg, at Grønbechs dialektiske idé om subjektiv objektivitet eller objektiv subjektivitet er forud for samtidens videnskabsteoretiske diskussion og tydeligt peger frem mod både 1960'ernes positivismekritik og den samtidige hermeneutiske debat med navne som Bultmann og Gadamer. Uden at anvende disse begreber øver Grønbech med sine overvejelser en indgående kritik af positivismen, ${ }^{75}$ ligesom han dermed bidrager væsentligt til afklaring af den historiske forståelses og fortolknings problematik. ${ }^{76}$ Med dette syn på, hvad humanistisk forskning er, kan Grønbech efter mit skøn hjælpe os ud over de håbløse valg mellem objektiv og subjektiv, mellem beskrivelse og fortolkning, mellem forklaring og fortolkning og mellem historisk og fonomenologisk eller hermeneutisk metode, som har præget religionsvidenskaben og andre humanistiske discipliner gennem de sidste to-tre generationer. ${ }^{77}$

Afslutningsvis skal vi kort vende tilbage til karakteristikken af Grønbechs »metode«. På baggrund af gennemgangen i dette afsnit må vi betegne Mitchells og Prytz-Johansens betegnelser som upræcise og forvirrende. Det er hverken dækkende eller klarende at benævne hans »metode« som »psykologiserende religionshistorie« (Mitchell) eller som »religionsfænomenologi« henholdsvis »religionsfænomenologi på psykologisk basis « (Prytz-Johansen). Hverken psykologi eller religionsfænomenologi er passende begreber til karakteristik af Grønbechs måde at arbejde på. De er begge flertydige og fremkalder bestemt ikke de rette associationer. Grønbechs fremgangsmåde er endvidere langt mere kompleks, end det fremgår af de foreslåede betegnelser. Overhovedet lader hans "metode« sig ikke gribe i et begreb, men vi bliver nødt til at operere med en række betegnelser, således som det er forsøgt ovenfor.

\section{Konklusion}

Hvad kan vi nu lære af Grønbech? Kaster man et blik på den aktuelle internationale og danske debat om religionsvidenskaben, skulle man ikke tro, at Grønbech nogensinde havde eksisteret. Man får i alt fald let det 


\section{Hvad kan vi lære af Grønbech?}

indtryk, at Grønbech så afgjort ikke har noget at byde på i dag. Dette indtryk forstærkes ved læsningen af Prytz-Johansens nye bog, i hvilken forfatteren slet ikke forsøger at aktualisere Grønbech og overveje, om og evt. hvordan hans indsigter kan udnyttes i dag. Måske kan man finde en del af forklaringen på dette forhold dels i Grønbechs egen uvilje mod »hypoteser «, »teorier « og »metoder « og dels i hans modvilje mod at give en sammenfattende beskrivelse af sin »metode«. Men uanset hvad årsagerne kan være, er den herskende tavshed uretfærdig, fordi Grønbech kan lære os det allervigtigste $\mathrm{i}$ vort håndværk og desuden en hel del andet.

Grønbechs altafgørende bidrag til religionsvidenskaben er selve hans begreb om videnskab og hans syn på forholdet mellem videnskab og kultur. Videnskab er ifølge Grønbech en personlig sag, og dens resultater er aldrig definitive, men altid foreløbige og altid under forandring. ${ }^{78}$ Videnskab er samtidig kulturarbejde. ${ }^{79}$ Hvad enten vi vil det eller ej, så spiller videnskaben en rolle i kultur og samfund. Det vigtigste, Grønbech har at lære os, er derfor, at forskeren har et ansvar over for sine medmennesker, over for samfundet og over for kulturen.$^{80}$ Man skulle tro, at vi havde lært denne lektie under 1960 'ernes og 70'ernes opg $ø$ r med positivismens falske objektivitetsbegreb. Det tyder 80 'ernes debat, eller måske rettere, mangel på debat om religionsvidenskabens rolle i samfundet imidlertid ikke på. ${ }^{81}$ Her kunne man naturligvis henvise til Jung-skolen og Eliade som eksempler på forskere, der tager dette ansvar på sig. Der er givetvis også et vist slægtskab mellem dem og Grønbech. Der er imidlertid også forskelle både i opfattelsen af religion og i holdningen til såvel de historiske religioner som til vor egen kultur og vor fremtid: Og her er det helt afgørende for mig, at Grønbech ikke, som Eliade, mener, at vor tids »frelse « skal komme fra religionerne eller religionshistorien. ${ }^{82} \mathrm{Jeg}$ tager hermed afstand fra den tolkning af Grønbech, at det var hans drøm at genoplive de arkaiske helhedskulturer. ${ }^{83}$ Grønbech indså klart, at noget sådant er umuligt. ${ }^{84}$ I stedet peger han på menneskets ansvar over for næste og natur. Derfor er der efter min mening stadig hårdt brug for Grønbech som læremester i det afgørende spørgsmål om forskerens ansvar over for samfundet. Religionsforskeren arbejder med selve nerven i kultur og samfund. Det er derfor hans ansvar at bidrage med sin viden til den aktuelle kulturdebat om samfundets nutid og fremtid.

Grønbech kan imidlertid også lære os en hel del andet. I direkte forlængelse af hans markante opfattelse af forskerens ansvar over for sam- 


\section{Per Bilde}

fundet ligger hans egenartede begreb om, hvad religion egentlig er. Karakteristisk nok giver Grønbech, så vidt jeg ved, intetsteds nogen præcis definition af religion, og han er i øvrigt heller ikke særlig klar på dette punkt. På den anden side er det tydeligt, at religion for ham er selve livsnerven i en kultur, det, der holder kulturen sammen, kulturens eller selve livets form, som han kalder det. Religion er »livet selv i dets højeste potens $\ll^{85}$ Religion er altså for Grønbech ikke noget, der er klart adskilt fra det profane, således som det er tilfældet hos Durkheim og Otto. Religion er heller ikke blot at begribe som en eller flere funktioner i samfundet og hos individet. ${ }^{86}$ Men religion repræsenterer de grundlæggende ordnende, meningsbærende og dermed livsfremmende træk i menneskelivet, således som det også er tilfældet hos van Baal og van Beek. ${ }^{87}$

Det er derfor konsekvent, at Grønbechs »metode« er holistisk. Jeg begriber endnu ikke, hvorfor han havde så meget imod begreberne metode, teori og hypotese. Det skyldes måske hans bevidsthed om at arbejde så radikalt anderledes end sine med traditionelle metoder arbejdende religionshistoriske kolleger. Det skulle ikke undre mig. Alligevel er hans holdning i denne sag overraskende. Spørgsmålet er dog ikke vigtigt. Langt vigtigere er det, at Grønbech de facto arbejdede konsekvent med sin egen komplekse fremgangsmåde, som det er beskrevet ovenfor.

Endelig kan vi måske lære af Grønbechs fremstillingsform. Han skrev alle sine bøger $\mathrm{i}$ et levende og medrivende prosadansk. Og han undlod konsekvent at belaste disse med lærde indledninger, ekskurser og fodnoter, ligesom debat med andre forskere næsten ikke forekommer. De allernødtørftigste oplysninger og henvisninger giver han i reglen i kortfattede noter bag i bogen. Man kan strides om denne form. Man kan hævde, at Grønbech lader laseren i stikken ved at forholde ham eller hende andre lærdes opfattelser og ved at gemme ofte nødvendige henvisninger så langt af vejen. ${ }^{88}$ Man kan også kritisere Grønbech for, at han ikke indlod sig i debat med andre forskere. ${ }^{89}$ Men der er ingen tvivl om, at Grønbech hermed fulgte en bevidst valgt linie, nemlig et forsøg på også i selve fremstillingsformen at overvinde kløften mellem videnskaben og folket eller kulturen. ${ }^{90}$ Han ville skrive, så alle kunne læse og forstå det, netop fordi han var sig sit ansvar som videnskabsmand over for samfundet bevidst. Vi kan således lære af Grønbech, at forskerne ikke bør isolere sig fra folket og blot skrive lærde værker til og for hinanden. I stedet er det opgaven ved hjælp af forskningen at bidrage til det fælles liv i samfundet. 


\section{Hvad kan vi lare af Grønbech?}

Man kan naturligvis diskutere Grønbechs resultater. Nogle af hans værker står stærkt i forskningshistorien, især Vor folkeat, Mystikere i Indien og Europa, Hellenismen og Hellas, mens andre står svagere. Det er altid et åbent spørgsmål, om det i det enkelte tilfælde virkelig er lykkedes Grønbech at få fat på helheden og få denne tilstrækkelig klart fremstillet. Man kan også diskutere Grønbechs »metode « og spørgsmålet om, i hvilken udstrækning han selv evnede at føre den ud i livet. Jeg har allerede været inde på, at Jesus Menneskesønnen ikke er særlig vellykket, netop fordi Grønbech her forlod sin »metode « og i stedet lod sin fantasi tage magten. Videre kan man naturligvis drøfte Grønbechs kulturkritik og utopier. Der må foregå en løbende debat om diagnosen af vor europæiske kultur og om beskrivelsen af dennes rødder i kristendommen og hellenismen. Det samme gælder utopierne, om hvilke Grønbech primært ytrede sig negativt og i øvrigt rimeligt åbent. Man kan naturligvis også diskutere det, der efter min mening er kernen i det hele, nemlig den grundholdning, at forskeren har et særligt ansvar over for sit eget samfund. Jeg er imidlertid overbevist om, at vi i dansk religionsvidenskab og teologi i dag vil stå os godt ved på dette punkt at tage ved lære af Grønbech for således i vort eget arbejde at føre hans værk videre. ${ }^{91}$

\section{Litteratur}

Arendt, R., »Spændt, for spændt - Vilh. Grønbech, Jesus Menneskesønnen«, Berlingske Aftenavis, 11.4.1962.

Baal, J. van and Beek, W.E.A. van, Symbols for Communication. An Introduction to the Anthropological Study of Religion, Assen 1985.

Bilde, P., »Billedsproget - en ny udvej for teologien?« Religionsvidenskabeligt Tidsskrift, 9, 1986, 77-84.

Bolle, K., "Myths and Other Religious Texts«, i: F. Whaling (ed.), Contemporary Approaches, I, 297-363.

Brun, L., »Vilh. Grønbech, Paulus«, Norsk Teologisk Tidsskrift, 1941, 114118.

Bukdahl, J. K., »Den misforståede Grønbech«, (Aarhuus Stiftstidende 20.10.1974), i: Frihed og frigørelse, Århus 1980, 277-284.

Bultmann, R., »Ist voraussetzungslose Exegese möglich?« (opr. 1957), i: Glauben und Verstehen, III, Tübingen 1965, 142-150.

Eliade, M., Images and Symbols, Kansas City 1961. 


\section{Per Bilde}

Grønbech, K., »Ved Vilh. Grønbechs død «, Frie Ord, 4-5, 1948, 169-176. Hansen, B. H., Omkring Heretica. Vilhelm Grønbechs forfatterskab som forudsatning for Hereticas første årgange med saerligt henblik på Ole Wivels produktion, Arhus 1972.

Hansen, M., „Professor Vilh. Grønbechs Trilogi: Bøgerne om Jesus, Paulus og Kristus«, Dansk Teologisk Tidsskrift, 1942, 233-245.

Hermelin, H., »Kampen om Människan. Några antydningar om Vilhelm Grønbechs författerskap«, Frie Ord, 4-5, 1948, 185-192.

Hill, »Sociological Approaches (1)«, i: F. Whaling (ed.), Contemporary Approaches, II, 89-148.

Hind, T., »Kætteren«, i: Engle uden basun, Fredensborg 1958, 9-41.

Holst, P., Vilhelm Grønbech. En bibliografi, København 1948.

Jensen, P. Johs., »Filologen Vilh. Grønbech«, Frie Ord, 4-5, 1948, 193-205. Jørgensen, P. H., »Jesus plus, Kristus minus, V. Grønbech, Kristus«, Berlingske Aftenavis, 1.12.1970.

Kehrer, G. and B. Hardin, »Sociological Approaches (2)«, i: F. Whaling (ed.), Contemporary Approaches, II, 149-177.

King, U., »Historical and Phenomenological Approaches«, i: F. Whaling (ed.), Contemporary Approaches, I, 29-164.

Koch, Hal, »Vilhelm Grønbech og »Frie Ord««, Frie Ord, 4-5, 1948, 215 217.

Larsen, K. Olesen, »Vilh. Grønbechs Evangelium«, Tidehver, 1944, 3-6, 14-21 og 25-36.

Mitchell, P. M., Vilhelm Grønbech. En indføring, København 1970.

Mortensen, V., »Den indfølende fortolkning, Vilh. Grønbech, Kristus den opstandne Frelser«, Information 19.9.1970.

Munck, J., »Grønbechs Trilogi om Urkristendommen«, Dansk Teologisk Tidsskrift, 1943, side 29-49.

Nielsen, K., »Billedsprog - eksegese - teologi «, Religionsvidenskabeligt Tidsskrift, 9, 1986, 85-92.

Oepke, A., »Jesus der Menschensohn«, Theologisches Literaturblatt, 63, 1942, 202-204.

Prytz-Johansen, J., »Vilh. Grønbech. Livets Søn«, Frie Ord, 4-5, 1948, $177-$ 184.

Prytz-Johansen, J., Religionshistorikeren Vilhelm Grønbech, København 1987.

Pullich, F., »Vilhelm Grønbech in memoriam«, Frie Ord, 4-5, 1948, $162-$ 168. 


\section{Hvad kan vi lære af Grønbech?}

Riisgård, E., Vilh. Grønbechs kulturopgør, I-II, København 1974.

Rubow, P. W., Vilh. Grønbech, (opr. Dagens Nyheder 14.6.1933), København 1948.

Søe, N. H., »Vilh. Grønbech, Jesus, menneskesønnen - en fremstilling, der sprænges«, Kristeligt Dagblad, 27.2.1962.

Sørensen, J. Podemann, »Religionshistorikeren som levende menneske: J. Prytz-Johansen: Religionshistorikeren Vilhelm Grønbech, Gyldendal 1987«, Chaos, 8, 1987, 113-114.

Whaling, F. (ed.), Contemporary Approaches to the Study of Religion, I-II, Berlin-New York-Amsterdam 1984-1985.

Whaling, F., »Introduction«, i: F. Whaling (ed.), Contemporary Approaches, I, 1-28.

Whaling, F., »Comparative Approaches«, i: F. Whaling (ed.), Contemporary Approaches, I, 165-295.

Whaling, F., "An Additional Note on the Philosophy of Science and the Study of Religion«, i: F. Whaling (ed.), Contemporary Approaches, I, 379390.

Whaling, F., »The Study of Religion in a Global Context«, i: F. Whaling (ed.), Contemporary Approaches, I, 391-443.

\section{Noter}

1. Se til spørgsmålet om »holismen« Whalings »Introduction« (især I, 3-4, 7 og II, 18-19), hans artikel om »Comparative Approaches « og Kings omfattende fremstilling af »Historical and Phenomenological Approaches « (især I, 147). Til kritikken af Eliade og Jung, se især Whaling, I, 20-21 og 214-223, og King, I, 112-116.

2. Se hertil Whaling, I, 12-13, 20-21 (om Eliade), 214-220 (om Eliade), 220-223 (om Jung) og 242; King, I, 112-116 (om Eliade), samt Whalings artikel, "The Study of Religion in a Global Context « (I, 391-442). Ellers udmærker værket som helhed sig ved i meget ringe udstrækning at overveje dette spørgsmål.

3. Jf. Whalings "Additional Note on Philosophy of Science and the Study of Religion« (I, 379-390). På vort eget beskedne niveau kan jeg henvise til debatten mellem Kirsten Nielsen og mig om billedsproget i GT i Religionsvidenskabeligt Tidsskrift, 9, 1986 (jf. også min metodologiske diskussion med Svend Bjerg om hans disputats i Religionsvidenskabeligt Tidsskrift, 1, 1982). Kirsten Nielsen slutter dér sit bidrag med følgende spørgsmål: „Hvordan forstår du forholdet mellem engagement og videnskab? Vil du i forlængelse af din kritik af min bog sige, at ethvert engagement må holdes ude fra videnskabeligt arbejde, da det ellers slører den objektive sag, som synes at være målet if. dig? Eller er det farven på mit engagement, der generer dig? Min manglende evne til at beherske det/skjule det?? Hvorfor arbejder du selv med tekster på et fremmed sprog, fra en fortidig kultur? Og hvorfor gør du det så vedvarende og energisk? Hvad vil du med dine studier? « Den tolkning af Grønbech, som jeg fremlægger i det følgende, er også ment som en foreløbig og indirekte besvarelse af Kirsten Nielsens spørgsmål (jf. note 91). En fyldig besvarelse foreligger i en anden artikel, som vil komme i et senere nummer af Religionsvidenskabeligt Tidsskrift. 


\section{Per Bilde}

4. Grønbech er en ikke altid krystalklar og entydig skribent, hvorfor det er naturligt, at han i tidens løb er blevet opfattet på flere forskellige måder (jf. nedenfor). Det skal derfor understreges, at hvad der fremlægges i denne artikel, er at opfatte som (argumenter for) min tolkning af Grønbech.

5. Se hertil de udførlige fremstillinger hos Riisgård, II, 173-297, og Prytz-Johansen, 1987, 9-43.

6. En fortegnelse over disse findes hos Riisgård, II, 423-424. Riisgård har ligeledes udarbejdet en oversigt over Grønbechs bøger og artikler med tilhørende anmeldelser (II, 413422). Se hertil også P. Holsts Grønbech-bibliografi.

7. Grønbech skrev både en række digtsamlinger og to romaner, jf. Mitchell, 218-221; Riisgård, II, 301-324 (341), og Prytz-Johansen, 1987, 167-175.

8. Rïsgård har udarbejdet en udførlig oversigt over receptionen af Grønbech frem til 1973 (II, 345-397), og han har ligeledes sammenstillet en fortegnelse over litteraturen om Gronbech (II, 431-435, jf. 436-439).

9. Se herom nærmere hos Riisgård, II, 364-365 (Arne Sørensen), 149 og 365-368 (Askovkredsen) og 381-385 (Heretica). Om Grønbech og Heretica foreligger der en særskilt undersøgelse af B. H. Hansen.

10. Der er tale om et genoptryk af artikel i Dagens Nyheder i anledning af Grønbechs 60 års fødselsdag (14.6.1933). For kortfattede introduktioner til Grønbech henviser jeg også til Tage Hind, Olesen Larsen og Munck.

11. Således side $87 \mathrm{og} 242$. Der er her tale om en karakteristisk kritik, der ofte blev fremført mod Gronbech, jf. nedenfor i afsnit 6 (note 42).

12. Således f.eks. 1, 84-87, hvor Riisgård forsvarer Grønbech mod anklager for subjektivisme, fremført af bl.a. Arup og Søe, og II, 55-58, hvor han forsvarer ham mod kritik fra bl.a. E. Brandes og Frisch for, at Grønbech i Vor folkeat forherliger de voldsglade nordboere. Der foreligger i øvrigt en interessant anmeldelse af Riisgårds store værk i Jørgen K. Bukdahl, Frihed og frigørelse, Århus 1980, 277-284.

13. Side 82, hvor Prytz-Johansen citerer et brev fra Grønbech til Dora Winstedt af 10.10.1936.

14. Således side 90-93 med et udførligt citat fra forordet til bind I af Mystikere $i$ Europa og Indien. Se også Prytz-Johansen, 1987, 117, 123 og 154.

15. Jf. især side 25,29 og 158.

16. Jf. 1, 8-10, 17, 221-222; II, 13, 134-135 og 223-228.

17. Jf. side 7, 124 og 128. Se f.eks. Grønbech, »Videnskabens stilling i folkelivet « (opr. et foredrag fra 1912) i Kampen om mennesket, 16-30, 25, og Kampen for en ny sjal, 26.

18. Side 14. Således også Pullich, 163, og Podemann Sørensen i sin anmeldelse af PrytzJohansens bog (113-114).

19. Heller ikke Tage Hind søger at placere Grønbech forskningshistorisk, men nøjes med at bemærke, at Grønbech altid har »indtaget en særstilling inden for dansk videnskab« (side 19).

20. Se f.eks. Vor folkeœt, I, 171-173, og »Religionsskiftet «, 101 og 108.

21. Jeg tænker især på Kåre Grønbechs mindeartikel (side 170-171 og 174-175) og på Tage Hinds storartede portræt af »kætteren« Vilhelm Grønbech (f.eks. side 15-16), men også på P. Johs. Jensen (side 194) og Mitchell (f.eks. side 38).

22. Dette antydes i »Religionsskiftet « (jf. 87, 90-92 og 101) og udfoldes klart i Kampen for en ny sjol, især 76-78; i foredraget "Angst «, 15-23, og i Livet er et fund, København 1951, 7-11.

23. Jf. »Religionsskiftet «, 93, og Hellenismen, I, 8. Disse tanker udfoldes imidlertid først for alvor i Kampen for en ny sjacl, jf. 9, 18, 20-21, 32-34, 38-39 og 78-82. Se også Olesen Larsen, 17. 


\section{Hvad kan vi lare af Grønbech?}

24. Jf. det $\mathrm{i}$ note 22 nævnte foredrag og foredraget $»$ Religion « (48).

25. Således allerede i "Videnskabens stilling«, 21-22 og 28, men også i artiklen »Atombomben «, f.eks. 35-40, 56 og 62-63.

26. Således f.eks. Kampen for en ny sjoel, 82.

27. Jf. henvisningerne i note 22 og f.eks. Kristus, 97.

28. Dette kommer til udtryk i, at Grønbech i de kulturkritiske skrifter meget konkret behandler emner som kolonialisme, imperialisme, udpiningen af jorden, kvindesag, arbejderbevægelse og Sovjetunionen. Således især i »Atombomben«, Hvem er min noeste?, en del artikler i Kampen om mennesket, men også Kampen for en ny sjoel.

29. Kritikken af kristendommen og hellenismen foreligger især udfoldet $\mathrm{i}$ Kampen for en ny sjoel og Hvem er min naste?, dvs. i kulturkritiske skrifter, der er udgivet efter de videnskabelige værker om hellenismen og urkristendommen. Denne kritik antydes dog også i tidligere arbejder, f.eks. »Religionsskiftet «, jf. note 22 ovenfor.

30. Således allerede $\mathrm{i}$ »Videnskabens stilling (især 28), men ellers i Kampen om mennesket (»Kvindesag « og »Kvindesag og arbejderbevægelse «) og slutafsnittene i »Angst « (33-40), »Religion« (50-53), Kampen for en ny sjol (85-123), Hvem er min naeste? (4957) og »Atombomben $(58-69)$.

31. Jf. »Atombomben «, 33 og 58.

32. Kritikken af evolutionismen og den europæiske etnocentricitet udfolder Grønbech især i Kampen for en ny sjoel, men den er med i talrige andre skrifter. Det hedder f.eks. i "Atombomben«, at der ikke er tale om »en mindre afsporing på et eller andet tidspunkt i Europas historie. Vor kultur er vokset lige op af grunden, rank som et lys fra først til sidst; de grufulde virkninger skyldes samme vækst som betinger vor ideelle stræben, vore mest højtflyvende drømme om sjælens adel. Den skæbne der nu tvinger os i knæ, er en direkte $x$ tling af vor vilje til magt, til at beherske, kristne og civilisere al jorden $\mathrm{i}$ vort eget billede...« (33).

33. Det er derfor logisk, at Grønbechs kulturkritik tager til i styrke samtidig med og efter hans omfattende studier af hellenismen og kristendommens grundlæggelse i perioden 1935-1941. Til Europas angst for jorden og kødet, se især Kampen for en ny sjoel, 3240, 46 (angsten for kvinden) og 78.

34. Jf. især Kampen for en ny sjal, 37-44; Hvem er min noeste?, 22-26, og »Atombomben«, 11.

35. Jf. Kampen om mennesket, 151-185. Han kan også konkret efterlyse »et organ for fredsbevægelsen« (Hvem er min noeste?, 39). Ellers afviser Grønbech at levere en konkret utopi og nøjes i reglen med at henvise til »at begynde med at høre på hvad Jesus har sagt « (Hvem er min næste?, 53-54, jf. »Atombomben«, 64-68, og flere andre steder). Se også Mitchell, 228, og Pullich, 165.

36. Jf. artiklen »Kierkegaard og Grundtvig« i Kampen om Mennesket, 136-150.

37. Jf. også Mitchell, 35, 65-66 og 248.

38. Jf. Riisgård, II, 410.

39. Jf. Riisgård, II, 403-406 og 410, og Bukdahl, 284: »Hovedsagen, om den ret forståede Grønbech er et af de nyttige supplementer til den marxistiske samfundskritik, når Riisgård ikke at behandle i sin lange bog, og denne korte omtale nøjes med at minde om, at det er hovedsagen $\ll$.

40. Jeg tænker på de mange og store vanskeligheder, som de socialistiske lande under deres udvikling er løbet ind i, på de vældige omlægninger, der som følge heraf er i gang $i$ mange af disse (især Sovjetunionen, men også Ungarn, Kina og flere andre) og endelig på de socialistiske partiers mangel på succes i den øvrige verden (jf. især England).

41. Jf. Mitchell, 18, 137 og 143. Således også bl.a. Olesen Larsen, 4, 29 og 34.

42. Således f.eks. Arendt, Jørgensen, Olesen Larsen, 4; Michell, 153, 156 og 242; Munck, 31 
ff. og 47; Oepke og Søe (jf. ovenfor i note 11).

43. Således f.eks. Olesen Larsen, 27 og 34.

44. Jf. Mitchell, 178.

45. Se hertil også Riisgård, I, 84-87, og II, 55-58.

46. Jf. anmeldelser og modartikler af bl.a. Brun, M. Hansen, Olesen Larsen og Munck.

47. Jf. Prytz-Johansen 1987, 81-98, og gennemgangen ovenfor i afsnit 4, jfr. også Riisgård, I, 73 ff.

48. Jf. f.eks. Vor folkecet, I, 176-177; »Videnskabens stilling«, $21 \operatorname{og} 23, \operatorname{og}$ Jesus, 10. Se hertil også Riisgård, 1, 73-76.

49. Jf. f.eks. Vor folkeat, I, 151-156, og »Videnskabens stilling «, 23. Andre steder taler Grønbech om at lytte (f.eks. Jesus, 10) eller at se (f.eks. Kampen for en ny sjoel, 7).

50. Jf. f.eks. forordet i Mystikere i Europa og Indien, I; Hellenismen, II, 19; Jesus, 10-11, og Kampen for en ny sjael, 7. I »Videnskabens stilling « (23) taler Gronbech om at indoptage sit emne i sig, og i Kristus (65) bruger han formuleringen at blive samtidig med det. Der er naturligvis tale om en billedlig tale, der skal udtrykke den rette indstilling hos forskeren. Dét misforstår Viggo Mortensen i sin anmeldelse af Kristus, hvor hovedindvendingen kredser om Grønbechs tale om at blive samtidig med sit historiske emne.

51. Jf. »Videnskabens stilling «, 23.

52. Se det samme sted. I Kampen for en ny sjal (side 7) siger Grønbech, at det at skrive historie er »at lære sig selv dybere at kende...«.

53. Ud over det vigtige udsagn i brevet til Dora Winstedt (Prytz-Johansen, 1987, 82) vil jeg fremdrage følgende sætning fra »Videnskabens stilling«, 27: »Objektiviteten udelukker ikke digtning - tværtimod «.

54. Samme skrift, 23.

55. Jf. Prytz-Johansen, 1987, 84-85. Forfatteren anfører her en del af et vigtigt sted i Mystikere $i$ Europa og Indien, IV (om Herder), 236: »Man må lægge sig selv ind i et menneske for at få et andet menneske ud. Vi lever kun ved at give os hen, det har jo også Herder lært, ved at optage og give liv. Să bliver det ikke et geometrisk spørgsmål, hvor sjælen ender, men et levende problem hvor hans sfære skærer min og andre menneskers. Det er den højeste, ja den eneste objektivitet«. Jeg tror, at Grønbech har den samme sag i tankerne $\mathrm{i}$ »Videnskabens stilling «, 28: »Videnskab kræver som intet andet selvhengivelse og selvopofrelse . Hvad det er, der ifølge Grønbech skal suspenderes, antyder han i Vor folkeat, I, 176: »Det er en sørgelig kendsgerning at moderne udforskning af primitiv tankegang har ført os længere og længere bort fra en virkelig forståelse af fremmede kulturer og religioner. Europæeren hæmmes af sin naive tro på sit eget system og sin egen logik som målestok for alle ting...«.

56. Jf. f.eks. Vor folkecet, I, 176, og Paulus, 89 og 243-244.

57. Det er i denne sammenhæng, vi skal forstå Grønbechs udstrakte anvendelse af parafrasens »metode «, jf. især Mitchell, 88, 112, 116-117, 123 osv.

58. Jf. »Atombomben«, 35: "Forskerens kunst består ene og alene i at se med åbne, uhildede $\varnothing j n e$ på tingene, og at tænke klart over hvad øjnene har set, uden at lade sig binde af forudfattede begreber. Videnskab er ærlighed, kort og godt...«.

59. Jf. Tage Hind, 11 og 19; Prytz-Johansen, 1987, 55 ff; Riisgård, II, 345, og Rubow, 8.

60. Jfr. også Jesus, 10, og Paulus, 9, 11, 17, 20 og 65.

61. Jf. bogen Sprogets musik fra 1943. I Kampen for en ny sjal, 7-8, taler Grønbech om, at ethvert folk har sin »egen sang eller hymne «, som præger alt, hvad folket skaber, jf. også Hellenismen, I, 9, og P. Johs. Jensen, 196: »Sprogets Melodi forstår man ikke, før man har fattet Kulturens Melodi. Hvert eneste Ord hænger sammen med Helheden...«. 


\section{Hvad kan vi lare af Grønbech?}

62. Jf. f.eks. Vor folkeat, I, 151 ff; Paulus, 63-64, og Kristus, 153-154. Se hertil P. Johs. Jensen; Tage Hind, 11 og 21-24, samt Rubow, 8 ff og 12-13.

63. Se hertil H. Hermelin, 189, som her fremhæver objektiviteten som det, der frem for alt andet kendetegner Grønbechs videnskabelige arbejder.

64. Jf. M. Hansen, 245; Jørgensen; Olesen Larsen, 4, og Munck, 31, 38 og 41.

65. Jf. f.eks. Hellenismen, 1, 8, og Prytz-Johansen, 1987, 82.

66. Således også Søe i sin anmeldelse i 1962.

67. Jf. Jesus, 23, 26, 29, $33 \mathrm{ff}, 55,59 \mathrm{ff}$ osv.

68. Jf. Atombomben, 30.

69. Kåre Grønbech, 170, og Olesen Larsen, 6.

70. Grønbech må hermed siges at stå i modsætning til Durkheim og Rudolf Otto, som begge bygger deres definitioner af religion på en grundlæggende sondring mellem helligt og profant. Ifølge Grønbechs opfattelse må en sådan adskillelse betragtes som et udtryk for, at religionen har mistet sin fundamentale betydning som »livet i dets højeste fortætning (»Religion «, 44).

71. Jf. Whaling, I, 3-4 og 7, samt King, I, 147.

72. Jf. Whaling, I, 16-18, 23-24 og 211-212; King, I, 39-42, 73 ff og 87-108, og van Baal and van Beek, 201-213.

73. Grønbech kan derfor ikke tages til indtægt for den senere så udbredte antireduktionistiske ideologi.

74. Jf. Bultmann, 142-150.

75. Jf. f.eks. »Atombomben«, 21-24. Se hertil også Tage Hind, 9-10.

76. Jf. Whalings videnskabsteoretiske overvejelser, I, 379-390.

77. Jf. fremstillingerne i Whaling, f.eks. King, I, 40-41, 53 og 73 og K. Bolle, I, 319-320.

78. Jf. »Videnskabens stilling «, 23-24.

79. Jf. samme skrift, 21-28.

80. Således frem for alt $\mathbf{i}$ »Atombomben «, især 35 og $55 \mathrm{ff}$.

81. Atter kan jeg henvise til værket Contemporary Approaches, som ikke rummer mange spor af denne problematik, jf. note 2 .

82. Jf.f.eks. Images and Symbols, Kansas City 1961, især side 35. Se også note 2.

83. Sådan kunne man tolke Grønbechs »projekt $\ll$.

84. Jf. Hvem er min nceste? 53-54, og Kampen for en ny sjoel, 102-103.

85. »Videnskabens stilling«, 25, jf. »Religion«, 43-44.

86. F.eks. den at fremme social integration eller den at mildne personlige kriser, jf. afsnittene om religionspsykologi og -sociologi i Contemporary Approaches, II, 21-88 (D. Wulff); II, 116-118 (M. Hill) og II, 154-156 (Kehrer and Hardin).

87. Jf. Symbols for Communication, 247-252, hvor de udfolder deres forståelse af religion som menneskets grundlæggende forsøg på at kommunikere med sin omverden og sine medmennesker.

88. Således Mitchell, 104 og 162.

89. Der er dog en del eksempler på, at Grønbech ytrer sig om andre forskere, jf. f.eks. »Religionsskiftet«, 74, 82, 84 og 92; Jesus, 8-12; Hellenismen, I, 11-13, og Kristus, 7879.

90. Jf. især »Videnskabens stilling «, 28. (Som det vil ses, så har undertegnede langt igen, før den grønbech'ske kanon for fodnoter er efterlevet. Bedre held næste gang!).

91. Hermed mener jeg også at have antydet en besvarelse af Kirsten Nielsens spørgsmål (jf. note 3). Videnskab og engagement er ikke blot forenelige, men uadskillelige. Forskeren investerer al sin personlige energi $\mathrm{i}$ sit videnskabelige arbejde med at indfange og 


\section{Per Bilde}

rekonstruere sit emne: $\mathrm{Og}$ når det er sket, er han eller hun endvidere forpligtet til at tage stilling dertil i en aktualiserende refleksion over sagens relevans i vor kultursituation i dag. Disse engagementer kan ikke andet end have forskellige farver, bestemt som de er af forskerens person. De skal heller ikke skjules, men lægges åbent frem, som Grønbech lærer os det. Årsagen til min egen optagethed af den jødiske og kristne tradition er - ud over nysgerrighed og pligt - simpelthen at finde i disse traditioners uomgængelige betydning på godt og ondt for vor egen kultur. Pointen i mine indvendinger mod Kirsten Nielsens disputats vedrører faren - ikke for subjektivitet eller engagement - men for den subjektive vilkårlighed, der efter mit skøn ligger i hendes tale om billedsprogets polyvalens. Jeg kritiserer altså ikke - heller ikke i den nævnte artikel - Kirsten Nielsens personlige engagement. Ej heller hævder jeg, at dette styrer hendes forskning i den forstand, at det tager magten over sag og metoder. Også hendes særlige interesse for traditions-, redaktions- og virkningshistorie er naturligvis videnskabeligt velbegrundet. Jeg ønsker alene at pege på, at Kirsten Nielsens interesse for billedsprogets polyvalens og funktion $\mathrm{i} \mathrm{kraft}$ af denne dets flertydighed $\mathrm{og}$ dermed vaghed rummer en fare for vilkårlighed $\mathrm{og}$ dermed for subjektivisme for modtageren. Dermed mener jeg, at der $\mathrm{i}$ den aktuelle kontekst nok via billedsproget skabes engagement, men at det forbliver uklart, hvilket indhold engagementet har, især da i relation til billedsprogets afsender og til dets eget »objektive« indhold. I øvrigt henviser jeg til det fyldige svar til Kirsten Nielsen, der omtales i note 3.

\section{Summary}

"What can we leam from Grønbech?" - Vilhelm Gronbech (1873-1948) is so far the most important and well-known Danish historian of religion. In 1987, Professor J. Prytz-Johansen published a new book on Grønbech, and this is the immediate occasion for this article which surveys Gronbech's life and works, and the secondary literature on Gronbech before and including Prytz-Johansen. Its primary aim, however, is to describe Grønbech's sproject" and religio-historical »method" - these are unsatisfactorily treated by Prytz-Johansen - in order to reflect on their validity for us today. The conclusion is, primarily, that we from Gronbech may learn that also the science of religion is a public, cultural and political affair, and, consequently, that we as scholars need to become aware of this fact and of the responsibility vis à vis our society which follows from this fact. Secondly, we may learn from Gronbech's peculiar mmethod of "objective subjectivity" or "subjective objectivity" and from his "holistic" approach to religion. Further, we may leam something from his ideas or definition of religion. And finally, it would be fortunate if we today could learn a little from Gronbech's beautiful and straightforward way of presenting his results to the public. Consequently, there are good reasons not to forget Gronbech either in Denmark or abroad.

\section{Per Bilde}

Lektor, dr. theol.

Institut for Religionsstudier

Aarhus Universitet 